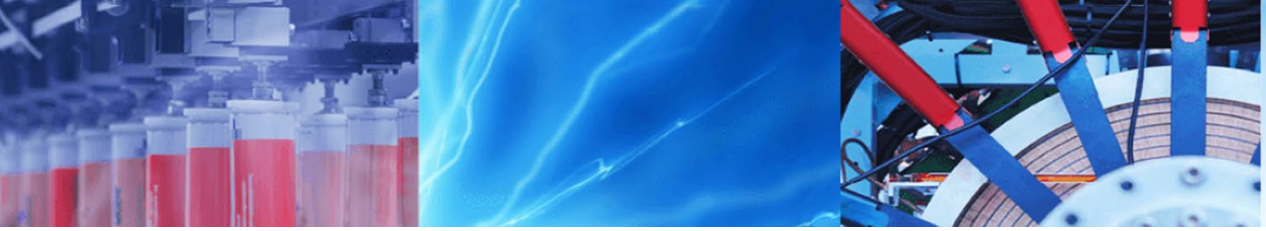

Research Article

\title{
Rainfall variability and dynamics of cropping pattern in Kashmir Himalayas: a case study of climate change and agriculture
}

\author{
Nusrat Batool $^{1}$ - Shamim Ahmad Shah ${ }^{1} \cdot$ Sajad Nabi Dar $^{1} \cdot$ Safiya Skinder $^{1}$
}

(c) Springer Nature Switzerland AG 2019

\begin{abstract}
Climate change has an adverse impact on the different spheres of life. Among the different human activities, agriculture is most affected by climate change which has been established by various studies at global and regional levels. It imposes serious constraints on the crop production which leads to changes in cropping pattern in general and in mountainous regions of the world in particular. In this regard, the present study aims to analyse the impact of rainfall variability on crop productivity and changes in cropping pattern in the north-western Himalayas. Mann-Kendall and Sen slope analyses were done to detect the changing trends in rainfall, whereas correlation coefficient was used to analyse the influence of rainfall variability on crop yield and the changing cropping pattern. The results indicate that rainfall has shown a decreasing trend from last few decades and has led to changes in the crop yield/production and cropping pattern in the region. Further, it was observed that crops in the region have shown different associations with rainfall, and as a result, area under some crops has increased while under certain other crops it has witnessed a contraction.
\end{abstract}

Keywords Climate change $\cdot$ Crop production $\cdot$ Cropping pattern $\cdot$ Mann-Kendall · Sen slope analysis · Correlation coefficient

\section{Introduction}

Climate change is already an established fact according to the IPPC Assessment Report [21]. From the report, it has been estimated that during the last century, the global mean surface air temperature increased on an average by $0.74^{\circ} \mathrm{C}$; however, the impact of climate change varied from place to place [21]. The Indian network of climate change assessment from 2010 to 2030 estimates an allround increase in the concentration of greenhouse gases for the Indian subcontinent. The annual mean surface air temperature in Indian subcontinent is projected to rise by 1.7 to $2.0^{\circ} \mathrm{C}$ by 2030 [20], and that temperature increase is more pronounced at higher than at lower elevation. The rainfall and the wind pattern are likely to shift with climate change, and unpredictable rains and heavy downpours are likely to be the rule rather than exception. The impact of the climate change is not confined to a particular area; it has shown its impact on the entire component of the biosphere from land to ocean and to air. The impact of climate change can be witnessed in the Indian subcontinent in general but in the mountainous areas like Himalayas in particular, in the form of receding glaciers and uneven rainfall in the region. India is an agrarian country with almost $65 \%$ of its population associated with agricultural activities. The impact of changing climatic factors like change in the temperature and rainfall has affected the agricultural productivity and forced people to change agriculture pattern. The Himalayan state of Jammu and Kashmir has also experienced impact of climate change in the form of increase in temperature and change in rainfall

Sajad Nabi Dar, sajaddar@kashmiruniversity.net; Nusrat Batool, nusratbatool.scholar@kashmiruniversity.net; Shamim Ahmad Shah, shamimcrocus@gmail.com; Safiya Skinder, safiyakhan745@gmail.com | 'Department of Geography and Regional Development, University of Kashmir, Srinagar 190006, India.

SN Applied Sciences (2019) 1:606| https://doi.org/10.1007/s42452-019-0599-9

Received: 30 January 2019 / Accepted: 13 May 2019 / Published online: 20 May 2019 
pattern, which has adversely affected agriculture, tourism and forestry.

Increasing global surface temperatures are very likely to lead to changes in precipitation and atmospheric moisture because of changes in atmospheric circulation, a more active hydrological cycle and increases in the water-holding capacity throughout the atmosphere [16]. An analysis of the precipitation shows that it has changed significantly in different parts of globe over the last century [37]. Climatic studies done in Northern Hemisphere show that precipitation has increased by $0.5-1 \%$ per decade, especially in mid and high latitudes, and annual average of regional precipitation increased by $7-12 \%$ for the area $30^{\circ}-85^{\circ} \mathrm{N}$ and by about $2 \%$ for the areas $0^{\circ}-55^{\circ} \mathrm{S}$ over the twentieth century [19, 52]. Amene and Krishnaiah [7] elucidated that there are a rising trend of rainfall in some months and a decreasing trend in some other months in northwest Ethiopia. Over the last 50 years, there has been a slight decrease in annual precipitation over China [53]. There have been marked increases in precipitation in the latter part of the twentieth century over northern Europe, with a general decrease southward to the Mediterranean [46].

Some past studies related to changes in rainfall over India have concluded that there is no clear trend in average annual rainfall over the country [22]. Trend analysis of rainfall data of 135 years (1871-2005) indicated no significant trend for annual, seasonal and monthly rainfall on an all-India basis [27]. Lal [29] indicates that the precipitation fluctuations in India have been largely random over the century, with no systematic change detectable on either annual or on seasonal scale. Mondal et al. [35] also suggested overall insignificant changes in the precipitation trends of Cuttack District, Orissa, with rising trend of precipitation in some months and decreasing trend in some other months. Guhathakurta and Rajeevan [18] found significant decreasing trend in three subdivisions (Jharkhand, Chhattisgarh and Kerala) and significant increasing trend in eight subdivisions (Gangetic West Bengal, West Utter Pradesh, Jammu and Kashmir, Konkan and Goa, Madhya Maharashtra subdivisions, coastal Andhra Pradesh, northern interior Karnataka) in monsoon precipitation during 1901-2003. Pattanaik and Rajeevan [42] found decreasing trend in monsoon rainfall over northwest and central India during 1941-2002.

In order to analyse the impact of climate on crop production, various studies have been carried out on global and national scale which indicates that there is positive correlation between the changing climatic variables and changing agriculture productivity and in some areas the change was found in the cropping pattern also. Parry et al. [41] analysed the global consequences to crop yields, production and risk of hunger of linked socio-economic and climate scenarios. Lobell and Field [30], Lobell et al. [31], found that crop yields are declining due to changing climatic variables like the precipitation and temperature. Allen et al. [6] and Thomson et al. [48] concluded that 1 degree increase in global temperature will lead to reduced productivity in some cultivated plants, such as $17 \%$ in maize and soya bean. Aninagyei and Appiah [8] observed that there exists a relationship between the average annual rainfall and temperature and the quantities of maize and rice produced annually. Muchow [36] analysed that the highest potential yield for maize occurred due to low temperature, resulting in a longer number of days between planting and maturity combined with a high incident radiation which caused high photosynthesis. Alexandrov and Hoogenboom [4] in their studies analysed the potential impact of climate change at a local level. Lui et al. [32] analysed the fluctuations in maize yield and yield gaps in the changing climate of northeast China. Malla [34] concluded that changing temperature and erratic patterns are affecting crop production in Nepal. Poudel and Shaw [43] observed that there is a negative impact of climate change on major crop yield in the mountainous parts of Nepal and came up with the finding that rise in temperature in the recent decades and the uneven rain have negative effect on the locals crops in terms of their productivity and cropping pattern. Food shortages and famines in sub-Saharan Africa are mostly a result of rainfall uncertainties and associated drought $[40,51]$. There are other researchers who have different observations. Affholder et al. [1] came up with the findings that crop yield is influenced by cropping system rather than climate. DeGraft and Kyei [12] conclude that average maize yield bears negative correlation with rainfall and temperature. Olesen et al. [38] predicted that high temperature could also open up new opportunities to expand areas of maize and other crops into regions currently constrained by cold. Gregory and Marshall [17] observed that warming has predominantly brought benefits to crop yield. Wang et al. [50] and Alexandrov and Gerrit [5] analysed that climate change has a significant impact on agriculture, primarily through its effect on crop yield. Tachieobeng et al. [47] provided reliable information towards understanding of future climate change and adaptation options to supplement existing knowledge that could be shared among farmers, media, public/private authorities and development partners interested in food security issues in semi-arid zones of sub-Saharan Africa, so that they could be prepared for the future change in climate.

In India, $60 \%$ of the total cropped area is still rain-fed and dependent on uncertainties of monsoon. This shows the dependency of Indian agriculture on climate [33]. Various studies have been conducted in India to analyse the relationship between crop production and changing climate. It is estimated that crop production loss in India by $2100 \mathrm{AD}$ 
could be $10-40 \%$ despite the beneficial effects of higher $\mathrm{CO}_{2}$ on crop growth [2]. Lal [28] concludes that $\mathrm{CO}_{2}$ increase would contribute positively to rice and wheat production in NW India. Saseendran et al. [45] while analysing the impact of climate change on the rice crop productivity in the state of Kerala concluded that by the middle of the next century an increase in rice yields (under rain-fed conditions) was possible. They also observed a reduction in crop duration in the state due to increase in temperature associated with the build-up of greenhouse gases in the atmosphere. Mall et al. [33] after analysing the works of several authors regarding the impact of climate change on Indian agriculture concluded that by the year 2080 when temperature increases are very large, the Indian agriculture will suffer the most.

In the light of these studies, the present research was undertaken to analyse the impact of climate variability on the crop production and changing cropping pattern of the Kupwara region. Thus, it investigates the rainfall trend in Kupwara District of Jammu and Kashmir and finds out the impact of rainfall variability on crop production and changing cropping pattern of the region.

\section{Study area}

The state of Jammu and Kashmir is the northernmost state of India, and the entire state lies within the Himalayas. The mountainous areas are very fragile and are susceptible to changing climate. Kupwara is one of the far-flung districts of Jammu and Kashmir State. Most of the people depend on agriculture for their livelihood. Any sort of change in agriculture can affect their entire livelihood pattern. Kupwara lies on the northern part of Kashmir valley with borders lying on the line of control that divides India and Pakistan. The district is located between $34^{\circ} 18^{\prime}$ to $34^{\circ} 47^{\prime}$ north latitude and $73^{\circ} 45^{\prime}$ to $74^{\circ} 3^{\prime}$ east longitude (Fig. 1). It is located about $1577 \mathrm{~m}$ above sea level, with geographical area of $2379 \mathrm{Km}^{2}$. The average annual rainfall in Kupwara region is $1066.9 \mathrm{~mm}$ with an average maximum and minimum temperature of $23.9^{\circ} \mathrm{C}$ and $2.9^{\circ} \mathrm{C}$. Also, there is a difference of $119 \mathrm{~mm}$ of rainfall between the wettest and driest month. Winter is generally severe with an average rainfall of $94.7 \mathrm{~mm}$ while summer is hot with roses and flowers on full

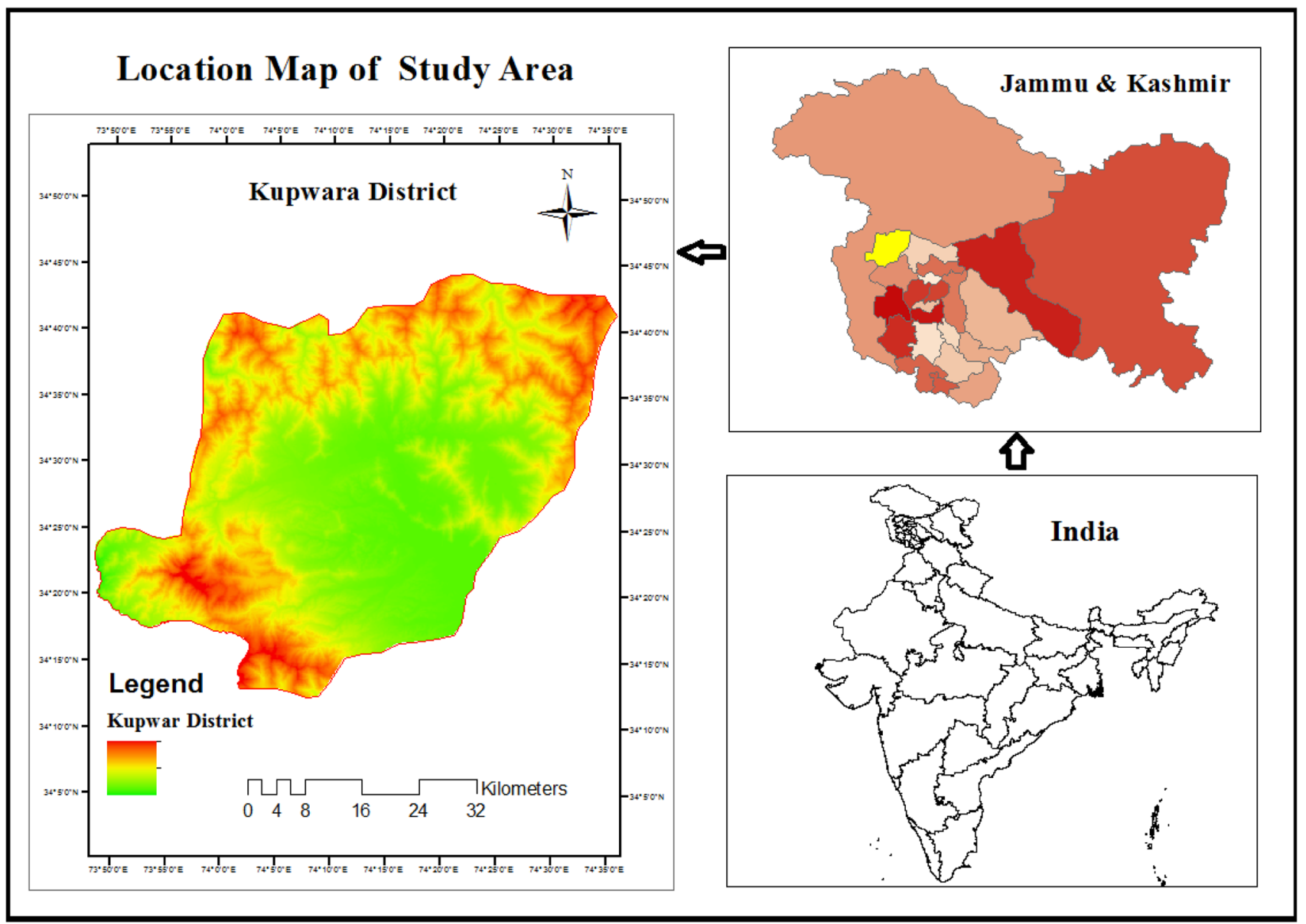

Fig. 1 Location map of Kupwara District 
bloom, having an average annual rainfall of $72.8 \mathrm{~mm}$. Thus, this region experiences temperate climate which is suitable for both horticultural and agricultural crops. A number of crops are grown in the district which include rice, maize, apple, pear, etc. but rice is the staple crop of the region. To analyse the impact of the climate change on agriculture, the following data set and methodology were adopted.

\section{Database and methodology}

In the present study, secondary sources of data were used. Rainfall data were obtained from the office of Indian Meteorological Department, Srinagar. Only one ground-based metrological station extends over the study region. Agriculture data in terms of productivity of different crops and area under different crops for different time periods were collected from the Directorate of Economics and Statistics, J\&K, Directorate of Horticulture, Kashmir. For the analysis of rainfall variability, Mann-Kendall test and Sen slope estimation were done to detect the trend in the hydro-meteorological parameters for which the rainfall data from 1977 to 2015 were used. The Mann-Kendall test and Sen slope consist of the following steps:

\subsection{Hypothesis testing}

Null Hypothesis There is no significance difference in the annual and the seasonal trend of rainfall in Kupwara region over a period of 38 years.

Alternate hypothesis There is a significant difference in the annual and the seasonal trend of rainfall in Kupwara region over a period of 38 years.

\subsection{Mann-Kendall}

The Mann-Kendall statistic $S$ is computed as follows:

$S=\sum_{i=1}^{n-1} \sum_{j=i+1}^{n} \operatorname{sgn}\left(x_{j}-x_{i}\right)$

where $x_{j}$ and $x_{i}$ are the annual values in years $j$ and $i, j>i$ respectively.

$\operatorname{Sgn}\left(x_{j}-x_{i}\right)$ is the sgn function as

$$
\begin{aligned}
\operatorname{Sgn}\left(x_{j}-x_{i}\right)= & \left\{+1, \quad \text { if }\left(x_{j-x_{i}}\right)>00,\right. \\
& \text { if } \left.\left(x_{j-x_{i}}\right)=0-1, \quad \text { if }\left(x_{j-x_{i}}\right)<0\right\}
\end{aligned}
$$

The variance $(\sigma 2)$ for the $S$-statistic is defined by

$V(S)=\frac{n(n-1)(2 n+5)-\sum_{k-1}^{m} t_{k\left(t_{k}-1\right)\left(2 t_{k}+5\right)}}{18}$

where $n$ is the number of data points, $m$ is the number of tied groups and $t_{k}$ denotes the number of ties to extent $k$. A tied group is a set of sample data having the same value. In case where the sample size $n>10$, the standard test statistic $Z_{s}$ is calculated as follows:

$Z_{s}=\left\{\frac{s-1}{\sqrt{v(s)}}\right.$ if $s>00$ if $s=0 \frac{s+1}{\sqrt{v(s)}}$ if $s>0$

The positive value of $Z_{s}$ indicates increasing trend while negative $Z_{s}$ value shows decreasing trend. Testing trend is done at the specific a significant level. When $\left|Z_{S}\right|>Z_{1-\frac{\alpha}{2}}$ the null hypothesis is rejected and significant trend exists in the time series. $Z_{1-\frac{\alpha}{2}}$ is obtained from normal distribution. In this analysis, we applied the MK test to detect whether a trend in the precipitation time series is statistically significant at significance level $a=0.05$ (or $95 \%$ confidence interval).

\subsection{Sen slope estimation}

If a linear trend is present in a time series, then the true slope (change per unit time) can be estimated by using simple nonparametric procedure developed by Sen. This means that linear model $f(t)$ can be described as

$F(t)=Q t+B$

where $Q$ is the slope and $B$ is the constantTo derive an estimate of the slope $Q$, the slope of all data pairs is calculated:

$Q_{i}=\frac{x_{j-x_{k}}}{j-k}$

where $i=1,2,3,4 \ldots N$ and $x_{j}$ and $x_{k}$ are the data values at times $j$ and $k(j>k)$.

If there are $N$ values $x_{j}$ in the time series, we get as many as $N=\frac{n(n-1)}{2}$ slope estimates $Q_{i}$. The Sen estimator of the slope is the median of these $N$ values of $Q_{i}$. The $N$ values of $Q_{i}$ are ranked from the smallest to the largest, and the Sen estimator is

$Q_{\text {med }}=\left\{\frac{Q_{n+1}}{2}\right.$, if $n$ is odd $\frac{1}{2}\left[Q_{\frac{n}{2}}+Q_{\frac{n+2}{2}}\right]$, If $n$ is even

$Q_{\text {med }}$ Sign reflects the data trend direction, while its value indicates the steepness of the trend. 


\subsection{Pearson correlation coefficient}

Correlation is a technique for investigating the relationship between two variables. Pearson correlation coefficient $(r)$ is a measure of strength of the association between two variables. Pearson correlation coefficient was used to know the correlation between the precipitation and crop yield. During the analysis, precipitation was taken as an independent variable and yield as dependent variable to estimate the impact of precipitation on yield. For evaluating significance level, $t$ test method was used.

\section{Results and discussion}

\subsection{Trend of rainfall in Kupwara}

For the analysis of rainfall trend (from 1977 to 2015), Mann-Kendall and Sen slope trend tests were used to detect the trend of annual rainfall in Kupwara region. Results show that rainfall in the Kupwara station has decreased during the last 38 years (1977-2015). Mann-Kendall test shows significant negative trend of 0.73 year with a sloping magnitude of $3.692 \mathrm{~mm} /$ year. Seasonal analysis for the Kupwara station was done for all four seasons that are spring (MAM), summer (JJA), autumn (SON) and winter (DJF). The Mann-Kendall and Sen slope trend tests indicate that rainfall in the Kupwara station has decreased for spring, summer and autumn seasons, whereas it shows positive trend for the winter season. Also, spring season shows significant negative trend of 1.28/ season/year with a sloping magnitude of $1.141 \mathrm{~mm} / \mathrm{sea}$ son/year, whereas winter season shows a positive trend of $0.31 / \mathrm{season} /$ year with a sloping magnitude of $0.174 \mathrm{~mm} /$ season/year.

The high amount of rainfall in winter season in Kupwara region is due to the western disturbance. Also, the valley is cut off from south-west monsoon; as a result, the spring, summer and autumn seasons receive low rainfall in the Kupwara region. Katiyar [24] observed that valley is generally cut off from the south-west monsoon by high range of Pir Panjal, but sometimes under favourable conditions monsoon winds are pulled into the Kashmir Valley. Vijay and Sharad [49] also detected a decreasing trend in a longterm data of monsoon rainfall of Kashmir. Ranjendran and Kitoh [44], using a super-high-resolution global model, have predicted reduced rainfall over Jammu and Kashmir in future. According to these authors, this reduction is associated with low perceptible water, reduced evaporation, lack of inflow of low-level moist air or transport of dry air from the Arabian region. Jaswal and Rao [23] while analysing the trend of various meteorological parameters like temperature and rainfall for ten stations in Jammu
Table 1 Average value, trend and magnitude of trend of rainfall in Kupwara on monthly basis from 1977 to 2015. Source: Indian Meteorological Department

\begin{tabular}{lcccc}
\hline & Rainfall $(\mathrm{mm})$ & \multicolumn{2}{l}{ Rainfall $(\mathrm{mm})$ decade } \\
\cline { 3 - 5 } & Average & Trend & $R^{2}$ & $\begin{array}{l}\text { Magnitude } \\
\text { of trend }\end{array}$ \\
\hline Annual & 1066.9 & $-0.73^{*}$ & 0.013 & -3.692 \\
Spring & 144.9 & $-1.28^{*}$ & 0.029 & -1.21 \\
Summer & 72.8 & $-0.75^{*}$ & 0.022 & -0.228 \\
Autumn & 42.3 & $-0.74^{*}$ & 0.01 & -0.225 \\
Winter & 94.7 & 0.31 & 0.001 & 0.176 \\
\hline
\end{tabular}

*Significance level at 5\% level

and Kashmir from 1976 to 2007, concluded that annual rainfall and rainy days trends are decreasing for both divisions of the state. Kumar et al. $[25,26]$ analysed that mountain areas act as a roadblock to circulation pattern of the atmosphere for both the summer monsoon and winter monsoon [14]. The winter climate of the north-western Himalayas is determined to a large extent by the western disturbances from October to May [13] and by south-west monsoon from July to September [10] (Table 1).

\subsection{Correlation between agriculture crop productivity and rainfall}

In this study, we analysed the crop yield and rainfall. In order to find relationship between them, the coefficient of correlation method was used. Our analysis showed positive correlation of annual rainfall with both rice and maize crops across the study years. The seasonal rainfall covers the period of spring and summer as these are the sowing and growing periods of the region. Seasonal analysis revealed strong positive correlation of spring and summer rainfall with rice and maize production. The correlation for maize was found to be statistically significant (at $5 \%$ level), whereas for rice it was not significant (at $5 \%$ level). From the analysis of rainfall variability, it was found that the annual rainfall has decreased in the last 38 years, whereas the seasonal precipitation has also shown a decreasing trend especially in sowing seasons when it is required the most (Table 2).

Table 2 Correlation between agricultural crop production and annual and seasonal rainfall. Source: Digest of Statistics (2015) and Indian Meteorological Department

\begin{tabular}{llll}
\hline Agricultural crop & Annual & \multicolumn{2}{l}{ Seasonal } \\
\cline { 3 - 4 } & & Spring & Summer \\
\hline Rice & 0.30467 & 0.1855 & 0.0483 \\
Maize & $0.17188^{*}$ & $0.0372^{*}$ & $0.1388^{*}$ \\
\hline
\end{tabular}

*Significant at $5 \%$ level 
Table 3 Correlation between horticultural crop production and annual and seasonal rainfall. Source: Directorate of Horticulture, Kashmir and Digest of Statistics, J\&K

\begin{tabular}{lccl}
\hline Horticultural crops & Annual & \multicolumn{2}{l}{ Seasonal } \\
\cline { 3 - 4 } & & Spring & Summer \\
\hline Apple & 0.6343 & 0.701 & 0.183 \\
Pear & $0.594^{*}$ & $0.515^{*}$ & $0.296^{*}$ \\
Walnut & 0.4315 & $0.193^{*}$ & $0.13^{*}$ \\
Almond & $-0.2332^{*}$ & $-0.179^{*}$ & $0.22^{*}$ \\
\hline
\end{tabular}

*Significant at $5 \%$ level

\subsection{Correlation between horticulture crop productivity and rainfall}

As the horticultural crops are mainly dependent on rainfall in the region, it becomes necessary to show correlation between the precipitation and productivity of horticultural crops (Table 3).

The coefficient of correlation of seasonal and annual rainfall for production of each horticultural crop was done for Kupwara region. The result revealed positive correlation of apple, pear and walnut with annual precipitation, whereas it showed negative correlation with almond. As far as seasonal precipitation is concerned, there is a positive correlation between summer precipitation and all horticultural crops. For spring season, it shows positive correlation with apple, pear and walnut while it shows negative correlation with almond. The correlation for pear, walnut and almond was found statistically significant (at 5\% level), whereas for apple it was not significant at $5 \%$ level.

\subsection{Variation in cropping pattern in Kupwara District}

The changing rainfall does not only affect the crop productivity but also the cropping pattern. With decreasing rainfall, the crops requiring more rainfall get affected and people prefer to shift towards those crops which need less rainfall, resulting into changing cropping pattern. The shift in cropping pattern is quite evident in Kupwara. The variation in rainfall has resulted into change in area under maize, apple, pear, walnut and almond which was analysed by computing percentage change in area (Table 4).

\subsection{Cropping pattern (2001-02 to 2005-06)}

Area under major crops in the district was about 314,883 hectares from 2001-2002 to 2005-2006. Taking into consideration all the selected crops of the study area, Table 4 clearly indicates that maize was the dominating crop of the region and accounted for about $45.80 \%$ of the total cropped area of the region. Followed by apple, accounting for about $22.75 \%$ of the total cropped area of the region, rice accounted for about $19.45 \%$ of the area. Area under walnuts contributes about $9.7 \%$ of the region. Pear and almond share about $0.55 \%$ and $0.017 \%$ of the area, respectively, which is almost negligible.

\subsection{Cropping pattern (2006-07 to 2010-11)}

Gross cropped area of major crops in the district increased from 314,883 ha in $2001-2005$ to $335,793.91$ ha in 2010-2011, thereby recording a growth of 20,910.91 hectares in the span of five years. Area under rice, apple, walnut and pear has increased, whereas area under maize has decreased from 2006-2007 to 2010-2011. About 3.57and 3.15-hectare areas of rice and apple have increased in this period, as high-quality improved seeds were used for rice cultivation and hybrid plants were used for fruit cultivation.

\subsection{Cropping pattern (2011-12 to 2015-16)}

Gross cropped area in this region has decreased by -4280.91 ha in five years. Area under apple, pear and walnut has increased at the cost of maize, as drastic decrease was found in maize area. Almond has also shown decline

Table 4 Variation in cropping pattern in Kupwara District Source Directorate of Horticulture, Kashmir and Digest of Statistics, J\&K

\begin{tabular}{|c|c|c|c|c|c|c|c|}
\hline S no. & Crop & $\begin{array}{l}\text { Area (in hectares) } \\
2001-2002 \text { to } \\
2005-2006\end{array}$ & Percentage (\%) & $\begin{array}{l}\text { Area (in hectares) } \\
2006-2007 \text { to } \\
2010-2011\end{array}$ & Percentage (\%) & $\begin{array}{l}\text { Areas (in hectares) } \\
2011-2012 \text { to } \\
2015-2016\end{array}$ & Percentage (\%) \\
\hline 1. & Rice & 61,254 & (19.45) & 77,306 & $(23.02)$ & 83,135 & $(25.077)$ \\
\hline 2. & Maize & 144,234 & $(45.80)$ & 126,462 & $(37.6)$ & 108,517 & $(32.733)$ \\
\hline 3. & Apple & 71,526 & $(22.75)$ & $87,046.5$ & $(25.9)$ & 94,835 & $(28.606)$ \\
\hline 4. & Pear & 1763 & $(0.55)$ & 1985 & $(0.59)$ & 2277 & $(0.686)$ \\
\hline 5. & Walnut & 36,051 & $(9.7)$ & $42,918.52$ & $(12.7)$ & 42,685 & $(12.87)$ \\
\hline \multirow[t]{2}{*}{6.} & Almond & 55 & $(0.017)$ & 75.89 & $(0.02)$ & 62 & $(0.018)$ \\
\hline & Total cropped area & 314,883 & $(100)$ & $335,793.91$ & $(100)$ & 331,513 & $(100)$ \\
\hline
\end{tabular}


in area. Other cereal crop, i.e. rice, has shown positive change in area.

It can be concluded from the results that there is significant change in cropping pattern in Kupwara region. It has been observed that area under maize has shown drastic decrease. The erratic rainfall is the main cause for this decrease since rainfall has shown positive correlation with maize productivity. Otegui et al. [39], Calvino et al. [11] observed that lower availability during the growing season as related to both low rainfall and shallow soils is the major constraint for maize grain yield in the southern pampas of Argentina. Within crop groups like cereals, there is an increase in rice production due to the use of improved seeds for rice cultivation and about 15,605 hectare area of rice is under irrigation facilities, thereby leading to an increase in the area under rice over the last 15 years, i.e. 2001 to 2015 [15]. It has also been observed that there is a shift in cropping pattern in favour of horticultural crops which is mainly influenced by economic factors. The State is implementing different schemes for boosting horticulture sector in the valley, e.g. RKVY, Mission for Integrated Development of Horticulture (MIDH), as horticulture sector plays an important role in the state's economy. Bazaz and Haq [9] observed that area under fruits and vegetables increased due to a series of measures initiated by the government at national level during 1980s and market opportunity. Akhtar and Acharya [3] analysed that there was shift in cropping pattern in favour of commercial crops which may be attributed to the development of infrastructure, technological innovations and introduction of new agricultural strategy( i.e. development of agricultural land, mechanization, manures and use of HYV seeds). There has been a complementary relationship between commercialization and cropping pattern of the state.

\section{Conclusion}

The present study has examined the trend of seasonal and annual rainfall and association between precipitation variability, crop production and the changing cropping pattern of district Kupwara. For analysing the trend in seasonal and annual precipitation of the region, data series with a length of 38 years, i.e. 1977 to 2015, was used. Kupwara region observes decreasing trend of annual rainfall. The analysis of seasonal rainfall time series showed a mixture of positive and negative trends. From the result, it has been analysed that spring, summer and autumn showed decreasing trend, whereas winter shows increasing trend.

For showing the relationship between the precipitation variability and crop production of Kupwara District for the period 2001 to 2015, data used include crop production and precipitation of the region. There was a positive correlation between the annual rainfall and crop production of the almost all the crops, except almond which showed negative correlation with spring rainfall. Through seasonal analysis, it was observed that there was a positive correlation between the crop production and rainfall of the region, except for almond crop which shows negative correlation with the spring rainfall.

The area under apple, pear and walnut increased at the cost of maize which showed a decreasing trend over the study period. This indicates that horticultural crops are showing increasing cropping area, whereas the maize shows decreasing trend over the last 15 years. Rainfall has shown decreasing trend for both spring and summer seasons, which has shown direct impact on productivity and cropping area of maize. This indicates that rainfall and economic factors have a close bearing on cropping pattern of the region.

Change in climate has a close bearing on the crop yield. With decrease in rainfall, the crop production has also decreased. Climate change also has major implications on cropping pattern. Decrease in rainfall has led to decrease in maize productivity and area under maize. However, it was also observed that economic factors and implementation of different schemes have also changed the cropping pattern of the region.

\section{Compliance with ethical standards}

Conflict of interest The authors declare that they have no competing interests.

\section{References}

1. Affholder F, Poeydebat C, Corbeels M, Scopel E, Tittonell P (2013) The yield gap of major food crops in family agriculture in the tropics: assessment and analysis through field surveys and modelling. Field Crops Res 143(3):106-118

2. Aggarwal PK (2008) Global climate change and indian agriculture: impacts, adaptation and mitigation. Indian J Agric Sci 78(10):911-919

3. Akhtar R, Acharya R (2015) Changes in cropping pattern in Jammu and Kashmir. Int J Adv Res Educ Technol 2(4):88

4. Alexandrov VA, Hoogenboom G (2000) Vulnerability and adaption assessments of agricultural crops under climate change in the South Eastern USA. Theor Appl Climatol 67:45-63

5. Alexandrov VA, Gerrit H (2001) Climate variation and crop production in Georgia USA during the twentieth century. Clim Res 17:33-43

6. Allen LH et al (2003) Carbon dioxide and temperature effects on evapo-transpiration and water use efficiency of soyabean. Argon J 95:1071-1081

7. Amene D, Krishnaiah P (2017) Analysis of rainfall trend (19792013) using non parametric trend in North West Ethiopia. Int J Innov Res Develop 6(12):180-186 
8. Aninagyei I, Appiah DO (2014) Analysis of rainfall and temperature effects on maize and production in Akim Achiase. Ghana Scholar Acad J Biosci 2(12B):930-942

9. Bazaz NH, Haq IU (2013) Crop diversification in Jammu and Kashmir: pace, pattern and determinants. IOSR J Humanit Soc Sci (IOSR-JHSS) 11(5):01-07

10. Bhutiyani MR, Ganju A, Singh D, Shekhar S, Kumar S, Chand H (2016) Spatio-temporal variability of climate change in highaltitude regions of NW Himalaya. In: Climate change, glacier response and vegetation dynamics in the Himalaya, pp 87-101

11. Calvino PA et al. (2003) Quantification of environmental and management effects on the yield of Late sown soybean. Field Crops Res 83(1): 67-77

12. De-Graft AH, Kyei CK (2012)The effect of climatic variables and crop areas on maize yield and variability in Ghana. Russ J Agric Soc Econ Sci 10(10)

13. Dimri AP, Niyogi D, Barros AP, Ridley J, Mohanty UC, Yasunari T, Sikka DR (2015) Western disturbances: a review. Rev Geophys 53(2):225-246

14. Dimri AP, Thayyen RJ, Kibler K, Stanton A, Tullos D, Singh VP (2016) A review of atmospheric and land surface processes with emphasis on flood generation along the southern rim of the Himalayas. Sci Total Environ 556:98-115

15. Directorate of Horticulture, Kupwara (2016)

16. Dore $\mathrm{MHI}$ (2005) Climate change and changes in global precipitation patterns: what do we know? Environ Int 31:1167-1181

17. Gregory PJ, Marshall B (2012) Attribution of climate change, a methodology to estimate the potential contribution to increase in potato yield in Scotland since 1960. Glob Chang Biol 18:1372-1388

18. Guhathakurta $P$, Rajeevan $M$ (2007) Trends in the rainfall pattern over India. Int J Climatol 28(11):1453-1469

19. Houghton et al. (2001) Climate change: the scientific basis, IPCC, 2001. Contribution of working group I to the third assessment report of the intergovernmental panel on climate change

20. INCCA (2010) Climate change and India: A $4 \times 4$ assessment, a sectoral and regional analysis for $2030 \mathrm{~s}$

21. IPCC (2007) The physical science basis, contribution of working group 1 to the fourth IPCC assessment report. Chapter 11. Regional climate projection

22. Jain SK, Kumar V (2012) Trend analysis of rainfall and temperature data for India. Curr Sci 102(1):37-49

23. Jaswal AK, Rao GSP (2010) Recent trends in meteorological parameters over Jammu and Kashmir. Mausam 61(3):369-382

24. Katiyar VS (1987) The Indian monsoon and its frontiers. InterIndian Publications, New Delhi

25. Kumar KK, Kumar KR, Ashrit RG, Deshpande NR, Hansen JW (2004) Climate impacts on India agriculture. Int J Climatol 24:1375-1393

26. Kumar KK, Rajagopalan B, Martin H, Gary B, Mark C (2006) Unraveling the mystery of Indian Monsoon failure during Elnino. Science 314:115-119

27. Kumar V, Jain SK, Singh Y (2010) Analysis of long-term rainfall trends in India. Hydrol Sci J 55:484-496

28. Lal M, Singh KK, Rathore LS, Srinivasan G, Saseendran SA (1998) Vulnerability of rice and wheat yields in NW India to future changes in climate. Agric For Meteorol 89:101-114

29. Lal et al (2001) Future climate change: implication for Indian summer monsoon and its variability. Curr Sci 81(9):1196-1207

30. Lobell DB, Field CB (2007) Global scale climate-crop yield relationship and the impacts of recent warming. Environ Res Lett 2(1):7
31. Lobell DB, Schlenker W, Costa-Roberts J (2011) Climate trends and global crop production since 1980. Science 333(6042):616-620

32. Lui ZJ, Yang XG, Hubbard KG, Lin XH (2012) Maize potential yields and yield gaps in the changing climate of North East China. Global Change Biol 18(12):3441-3454

33. Mall RK, Singh R, Gupta A, Srinivasan G, Rathore LS (2006) Impact of climate change on Indian agriculture: a review. Clim Chang 78:445-478

34. Malla G (2008) Climate change and its impact on Nepalese agriculture. J Agric Environ 9:62-71

35. Mondal A, Kundu S, Mukhopadhyay A (2012) Rainfall trend analysis by Mann-Kendall test: a case study of North-Eastern part of Cuttack District, Orissa. Int J Geol Earth Environ Sci 2(1):70-78

36. Muchow RC (1990) Effects of high temperature on grain growth in the field grown maize. Field crops Res 23:145-158

37. New M, Todd M, Hulme M, Jones P (2001) Precipitation measurements and trends in the twentieth century. Int J Climatol 21:1899-1922

38. Olesen JE, Carter TR, Diaz-Ambrona CH, Fronzek S, Heidmann T, Hickler T, Holt T, Minguez MI, Morles P, Palutikof JP, Quacmanda M, Ruiz-Ramos M, Ruback GH, Sau F, Smith B, Sykes (2007) Uncertainties in projected impacts of climate change on european agriculture terrestrial ecosystem based on scenarios from regional climate models. Clim Chang 81:123-143

39. Otegui et al (1995) Sowing data effect on grain yield component for different maize genotype. Agron J 87(1):29-33

40. Pankhurst $\mathrm{R}$, Johnson $\mathrm{DH}$ (1988) The great drought and famine of 1888-92 in North east. 3(4): 47-72

41. Parry ML, Rosenzweing $C$, Iglesias $A$, Livermore $M$, Fischer $G$ (2004) Effects of climate change on global food production under SRES emissions and socio-economic scenarios. Glob Environ Chang. 14(1):53-67

42. Pattanaik DR, Rajeevan M (2010) Variability of extreme rainfall events over India during Southwest Monsoon Season. Meteorol Appl 17:88-104

43. Poudel S, Shaw $R$ (2016) The relationship between climatic variability and crop yield in a mountainous environment: a case study in Lamjung District Nepal. Climate. 4(1):33

44. Ranjendran K, Kitoh A (2008) Indian summer monsoon in future climate projection by a super high- resolution global model. Curr Sci 95:1560-1569

45. Saseendran SA, Singh KK, Rathore LS, Singh SV, Sinha SK (2000) Effects of climate change on rice production in the tropical humid climate of Kerala. India Clim Chang 44:495-514

46. Scho"nwiese CD, Rapp J (1997) Climate trend atlas of Europe based on observations, 1891-1990. Netherlands Kluwer Academic Publishers, Dordrecht, p 228

47. Tachieobeng E, Gyasi E, Abekoe SAM, Ziervo-gel G (2010) Farmers' adaptation measures in scenarios of climate change for maize production in semi-arid zones of Ghana. in: 2nd international conference on climate, sustainability and development in semi-arid regions, Fortaleza, pp 16-20

48. Thomson AMRA, Brown NJ, Roseberger RC, Lazuralede, Benson V (2005) Climate change impacts for the conterminous USA. An integrated assessment, part 3. Dry Land Prod Gram For Crops Clim Chang 69:43-65

49. Vijay K, Sharad JK (2010) Trends in seasonal and annual rainfall and rainy days in Kashmir Valley in the last century. Quatern Int 212:64-69

50. Wang JX, Huang JK, Jun Y (2014) Overview of impacts of climate change and adaptation in China's agriculture. J Int Agric 13:1-17 
51. Wood A (1977) A preliminary chronology of ethiopian droughts. In: Droughts in Africa. Dalby D, Church RJH, Bezzaz F, pp 68-73

52. Xu ZX, Takeuchi K, Ishidaira H, Li JY (2005) Long-term trend analysis for precipitation in Asia Pacific Friend River Basin. Hydrol Process 19(18):3517-3532

53. Zhai PM, Sun A, Ren FM, Liu X, Gao B, Zhang Q (1999) Changes of climate extremes in China. Clim Chang 42:203-218
Publisher's Note Springer Nature remains neutral with regard to jurisdictional claims in published maps and institutional affiliations. 